\title{
Kontakt mellom lege og pasient etter avsluttet behandling?
}

\author{
Leger bør utvise stor varsomhet og sensitivitet i møte med tidligere og nåværende pasienter og respektere \\ deres grenser og integritet. Det er en god regel å la pasientens initiativ styre eventuell kontakt.
}

Dilemmaer knyttet til det å etablere private relasjoner til pasienter er tidligere diskutert i Tidsskriftet (1). Legeforeningens råd for legeetikk har nylig behandlet en klage fra en pasient som hadde avsluttet langvarig terapi hos en psykiater og der psykiateren senere tok kontakt med vedkommende ved to anledninger.

Klager hadde gått $\mathrm{i}$ intensiv psykoterapi hos psykiateren over flere år og valgte så å avslutte terapien. Et par år senere traff de hverandre tilfeldig på gaten i klagers nærmiljø. Psykiateren tok initiativ til en samtale om forhold i klagers privatliv som han kjente fra det terapeutiske samarbeidet. Psykiateren fortalte også om vansker i sin egen praksis. Klager uttrykte at det vel var uvanlig å stoppe opp slik og ga ikke-verbalt uttrykk for ønsket om å gå videre. Et par år senere kontaktet psykiateren igjen sin tidligere pasient med en e-post, der han blant annet var interessert i sider ved klagers arbeid. Igjen opplevde vedkommende at psykiateren invaderte privatlivet og brøt med sin «forpliktelse som behandler til å forvalte andres sårbarhet», som klageren uttrykte det.

\section{Rådets behandling}

Saken ble behandlet i Rådet for legeetikk på vanlig måte, med flere uttalelser fra begge parter. Psykiateren fremholdt i sine tilsvar at han ikke hadde oppfattet at den tidligere pasienten ikke ville ha kontakt med ham på gaten og at klager som et voksent menneske kunne ha avvist ham. Han fremholdt at hans e-post først og fremst var motivert av det forhold at han følte han hadde oppført seg klønete i sin henvendelse på gaten. Han beklaget at hendelsene hadde gjort klager vondt og at han var kommet i skade for å krenke ham.

Rådet vurderte saken ut fra kapittel I $§ 2$ i Etiske regler for leger, der det står: «Legen skal ivareta den enkelte pasients interesse og integritet. Pasienten skal behandles med barmhjertighet, omsorg og respekt. Samarbeidet med pasienten bør baseres på gjensidig tillit og skal, der det er mulig, bygge på informert samtykke.»

Rådet la til grunn at når en pasient velger å avslutte en lang samtalebehandling, er det et uttrykk for at vedkommende ikke ønsker videre kontakt. Videre vurderte rådet det slik at når en pasient har avsluttet et behandlingsforhold, er det pasienten som eventuelt kan ta initiativ til å ta kontakt igjen dersom han eller hun trenger eller ønsker det - ikke omvendt. Dette gjelder både kontakt av privat karakter og kontakt for eventuelt å gjenoppta behandlingen.

Rådet mente at psykiateren ved å være proaktiv i møtet på gaten og i sin e-post hadde krenket sin tidligere pasients integritet. Rådet ga psykiateren kritikk for å ha brutt $\S 2$ i kapittel I.

Rådet behandlet for noen år siden en liknende sak der en lege tok kontakt med en pasient $\mathrm{i}$ en forretning. Klageren mente den gang at henvendelsen var et brudd på taushetsplikten fordi den kunne oppfattes som avsløring av et lege-pasient-forhold. Rådet ga i sin tid også denne klageren medhold.

Etter rådets mening bør leger utvise stor varsomhet og sensitivitet i møte med tidligere $\mathrm{og}$ nåværende pasienter og respektere deres grenser og integritet. Det er etter rådets mening en god regel å la pasientens initiativ styre eventuell kontakt - det er pasienten som må velge å hilse ved tilfeldige møter, innlede til samtale eller etablere kontakt på annen måte.

\section{Karsten Hytten}

karsten@hytten.no

Rådet for legeetikk

Den norske legeforening

Karsten Hytten (f. 1953) er dr.med. og avtalespesialist i psykiatri samt lærer og veileder ved Institutt for psykoterapi. Han har erfaring fra akuttpsykiatri og poliklinisk psykiatri samt forskningsbakgrunn innen mestringspsykologi og suicidologi.

Ingen oppgitte interessekonflikter.

\section{Litteratur}

1. Hytten K. Privat forhold mellom lege og pasient. Tidsskr Nor Legeforen 2011; 131: 1100.

Mottatt 26.9. 2011 og godkjent 6.10. 2011. Medisinsk redaktør Petter Gjersvik.

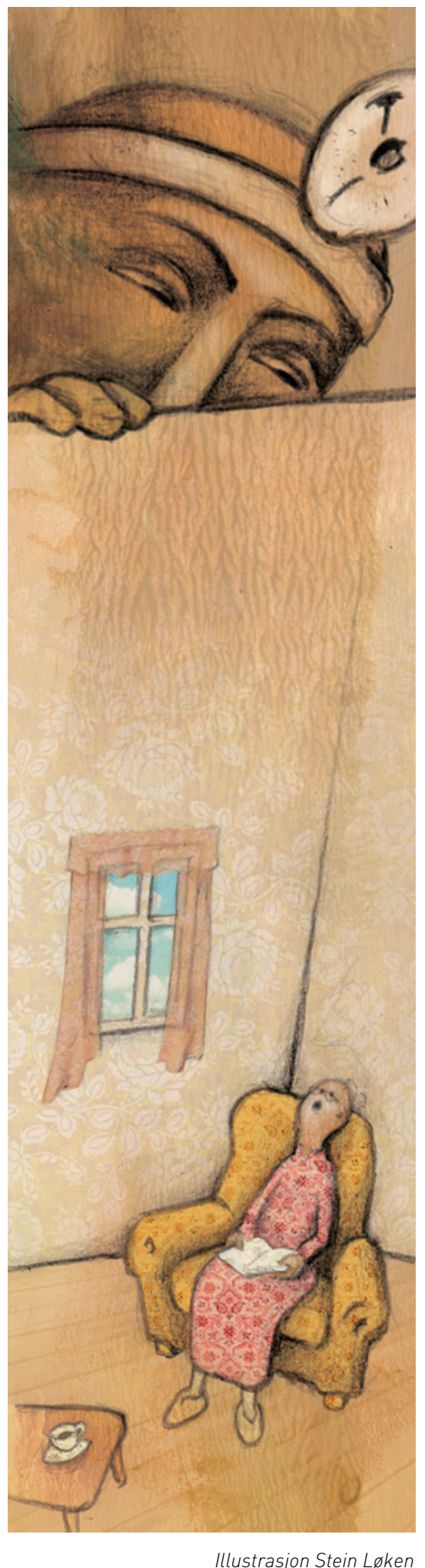

